\title{
Corn Yield as Altered by Using On-Farm Seed Priming, Different Nitrogen Levels and Soil Moisture Regimes
}

\author{
Kamil Sardar*, Khadim Dawar, Farooq Khan, Ikram Ullah, Jasim Iqbal and Abdul wahid \\ Department of Soil and Environmental Sciences, The University of Agriculture Peshawar, Pakistan
}

Submission: November 23, 2016; Published: December 07, 2016

*Corresponding author: Kamil Sardar, Department of Soil and Environmental Sciences, The University of Agriculture Peshawar, Pakistan, Tel: +923339800311; Email: kamilsardar@gmail.com

\begin{abstract}
The experiment was conducted at New Developmental Farm, of The University of Agriculture Peshawar during summer 2013 to study the effect of seed priming, nitrogen $(\mathrm{N})$ levels and soil moisture regimes on the yield and yield components of maize. Two separate experiments were conducted in RCB design, one under high moisture condition other under low moisture condition. Treatment combination of seed priming and $\mathrm{N}$ levels were kept in. Sub plots while moisture in main plots. Nitrogen was applied at $\left(0,75,150 \mathrm{~kg} \mathrm{~N} \mathrm{ha}^{-1}\right)$ in three split doses. Seed priming was consisted of dry seed, water soaked and seed primed in 0.2\% Phosphorus (P) solution. Days to emergence and Emergence $\mathrm{m}^{-2}$ of maize were significantly affected by moisture and seed priming while $\mathrm{N}$ effect was not significant. Low moisture plots resulted in higher days to emergence as compared to high moisture plots. Higher days to emergence were recorded for dry seed as compared to P primed seed and water soaked seed. Plant height and Number of leaves were not significantly affected by moisture, $\mathrm{N}$ levels and seed priming while the effect was significantly varied at different weeks. Similarly significant affect was recorded by moisture, $\mathrm{N}$ levels and seed priming during different weeks. Biological yield (BY) and Grain yield (GY) were significantly affected by nitrogen levels and seed priming while moisture effect was not significant. Higher BY and GY were obtained at $150 \mathrm{~kg} \mathrm{~N} \mathrm{ha}^{-1}$ for P primed seed and water soaked seed while dry seed and lower level of $\mathrm{N}$ resulted in lower yields. Minimum biological and grain yield was attained at $0 \mathrm{~kg} \mathrm{~N} \mathrm{ha}^{-1}$.
\end{abstract}

Keywords: Nitrogen (N); Seed priming; Water soaking; Moisture regimes; Maize

\section{Introduction}

Maize (ZeaMays) belongs to the grass family Gramineae or panacea. The genus Zeaconsists of four species of which only ZeaMays Spp. is economically important. Two types of maize are sowed, spring season maize and summer season maize. Summer season maize (ZeaMays) is one of the most significant cereal crops in the world grown over an area of $132 \mathrm{~m}$.ha with a production of $570 \mathrm{~m}$.t. It is the crop with the highest per day productivity. Maize is one of the oldest of the cultivated crops. Maize is a universal crop grown in the developed and developing countries over an extent of 1400.79 Lehar. In Pakistan maize is the third important cereal grain after wheat and rice. It is mostly grown in KPK and Punjab. In Pakistan. During 2002-2003 it was planted on 935500 hectares, with total production of 1737100 tons. Average yield was $1857 \mathrm{~kg} / \mathrm{ha}$. In KPK maize was shown on 506400 hectares with production of 847500tons and average yield was $1674 \mathrm{~kg} / \mathrm{ha}$. (ASP 2002-2003).
Maize has three possible uses: as food, as a feed for live stock and as industrial Products. As a food, Maize is a new traditional oil seed crop and the oil content in general varies from 2.5 to 5.5 percent. Maize acts as a source in the manufacture of starch, syrup, dextrose, oil, gelatin, lactic acid etc. Corn flour is used as a thickening agent in the preparation of many edibles like soups, sauces and custard powder. Maize fodder is highly nutritious and is liked by the livestock, so it provides nutrients for both humans and animals. It also serve as an industrial products based on the physical and chemical properties of the cob. The water in which the maize grains are soaked for the manufacture of glucose is used for growing penicillin moulds. Phosphorus classified as a macronutrients, is also a component of certain enzymes and protein ADP and ATP, RNA and DNA and chitin, ADP and ATP provide the energy required by all biological processes. Seeds are high in phosphorus which play an important part in their 
development.Phosphorus play an important role in root health and the ability of plants to batter tolerate soil born diseases. Root flourishes when adequate phosphorus exists. Deficiency of phosphorus will effect root growth and bud development poor seed development and poor fruit quality and size may result.

Seed quality can have profound influence on yield and quality of crops. In particular seed of high viability and vigor is essential for achieving high yield and quality.Seed priming comprises the soaking of seed in water or any chemical or nutrient solution and drying back to the storage moisture until use. The seed priming induces a range of biochemical changes in the seed that are required to start the germination process such as breaking of dormancy, hydrolysis or metabolization of inhibitors, imbibitions and enzyme activation. Some or all of these processes that precede the germination are triggered by priming and persist following the re-desiccation of the seeds As phosphorus are very essential for plants and human body. Seed priming with P improve emergence and seedling fresh and dry weight as compared to dry seed and showed that water and nutrient priming can be used as tool to accelerate and improve emergence and early growth of maize (Arif et al. [1].

Globally, fertilizer nitrogen (N) applications are approximately 80 million tones, with half being applied in developing countries and the other half in developed countries. It has been estimated that by the year 2025 the consumption of nitrogen fertilizer will increase 60 to 90 percent, with two-third of this being applied in the developing world (Galloway et al., 1995). This trend in fertilizer use is mostly driven by the need of developing countries to keep food supply up with population growth. It has been projected that by year 2020 world population will be more than 8 billion people, with more than 90 percent of this additional growth concentrated in developing countries. However, the efficiency of $\mathrm{N}$ fertilizer use tends to be low in this system. Nitrogen plays an important role in crop life. It is one of the most important nutrients needed by plants in large quantities. Adequate nitrogen promotes vigorous vegetative growth and deep green color. Nitrogen has been recognized as one of the most limiting nutrient. Its use and demand is continuously increasing day by day.

The soil and climatic conditions of Pakistan are favorable for Maize and barley, but their yield is still very low as compared to other leading countries. Besides other factors, time and amount of irrigation are two important factors upon which production of a bumper crop depend in irrigated areas. Irrigation is needed in many areas of the country for good crop growth and proper grain development as rainfall is inadequate and erratic throughout the country. For temperate cereals there are two critical periods during which water stress greatly reduce yield, i.e. the period from anthesis to the milk stage. Maize usually needs 4 to 6 irrigation depending upon latitude, soil type cultivar, rainfall and other factors affecting evapotranspiration. Priority in watering should be assigned as follows: adventitious roots development, an thesis, milk stage. Tillering, spike emergence and subsequent irrigation should be given accordingly to the need of the crop and availability of water. In this experiment we investigated the effect of seed priming on the plant growth and yield of maize at low moisture condition (means low applied irrigation at normal level).

\section{Review of Literature}

\section{Seed priming}

Rashid et al. [2] reported that seed priming has been shown to improve plant stands and provide benefits in terms of early maturity, reduced disease and increased yields in a range of crops grown on normal soils.

Arif et al. (2 003) seed soaked for 8 hours emerged earlier and higher in number (30.1) as compared to non-soaked seed (14.7) of mug bean. They concluded that soaking hastened emergence in mug bean as compared to non-soaked seed. soaked seeds of barely cv. Arabia as wad for 0-48 hours in water and for 12 hours in solutions containing 5-500m M, of $\mathrm{P}, \mathrm{Zn}$ and $\mathrm{P}+\mathrm{Zn}$ and dried back to $12 \%$ moisture until further use. Seeds were incubated at $10{ }^{\circ} \mathrm{C}$, and germination was evaluated over a 6-8 day period. Water priming for 12 hours with subsequent seed storage of up to 9 weeks increased germination rate from $65 \%$ to $95 \%$ and enhanced germination by 3 days when compared to unprimed seeds. Addition of $10 \mathrm{mM} \mathrm{Zn}$ and $50 \mathrm{mM} P$ to the priming solution increased the $\mathrm{P}$ and $\mathrm{Zn}$ content of the seeds without affecting germination.

Arif et al. [1] reported that dry seed took 10 days to reach $50 \%$ emergence while primed seed took 5 days to $50 \%$ emergence. Improved emergence (\%) was noted in water soaked seed followed by seed primed in $2 \% \mathrm{P}+2 \% \mathrm{Zn}$ and $1 \% \mathrm{P}$ solutions as compared to dry seed. Water soaked and nutrient primed seeds produced more seedling weights compared to dry seed.

Rashid et al. [2] documented that seed priming increased grain and straw yield of barley. Grain yield increase due to priming (soaking seeds in water prior to sowing) was up to $53 \%$ in the participatory trials. Optimum duration of priming was between 12 and 16h, and the response to priming was better in low potential environments than under better conditions. Priming was also more advantageous on saline-sodic than on saline soils, possibly as a result of the water content of the soil. It was concluded that "on-farm" priming of barley could be recommended to farmers of KPK and in similar environments in other parts of the world, who produce barley both for grain and for fodder.

Arif et al. [3]conducted experiment at the Agricultural Research Farm of NWFP Agricultural University Peshawar during spring 2005. Seeds of maize cultivar Azam was primed in $1 \%$ phosphorous (P), $2 \% \mathrm{P}+2 \%$ Zinc $(\mathrm{Zn})$ or $2 \% \mathrm{P}+2 \% \mathrm{Zn}$ solutions for 12 hours. The control treatment was dry seed. Dry seed took 10 days to reach 50\% emergence. Water primed 
seed reached $50 \%$ emergence five days after sowing, advancing the earliness of emergence by five days compared to dry seed. Improved emergence (\%) was noted in water soaked seed followed by seed primed in $2 \% \mathrm{P}+2 \%$ zinc and $1 \% \mathrm{P}$ solutions as compared to dry seed. Water soaked in nutrient primed seeds produced superior seedling fresh and dry weights as compared to dry seed.

Khan and Khalil [4] noted maximum tillers $\mathrm{m}^{-2}$, grain spike ${ }^{-1}$, greater grain weight, biological yield and grain yield by seed primed in phosphorus solution. They also found that seed primed with phosphorus solution took minimum days to flowering and maturity as compared to other treatments.

Drought is a worldwide problem and continues to pose a serious constraint to global crop production. Recent global climate change has made the situation more serious as the frequency and severity of droughts has increased. Drought, through insufficient rainfall and poor distribution during growth, is one of the most important a biotic stresses affecting maize production. It is the single most important source of variation in yield over time; highlighting our continuing vulnerability with regards to this natural phenomenon.

\section{Nitrogen}

Khan (1985) concluded the effect of different levels of nitrogen ( $033.6,72.2,100.8$ and $\left.143.4 \mathrm{~kg} \mathrm{~N} \mathrm{ha}^{-1}\right)$ and phosphate (0. 14.7, 22.0 and $29.4 \mathrm{~kg} \mathrm{P} \mathrm{ha}^{-1}$ ) application on straw yield, days to maturity, germination and plant height of wheat. He found that increasing rates of nitrogen ( 0 to $143.4 \mathrm{~kg} \mathrm{ha}^{-1}$ ) increased straw yield and plant height but delayed maturity. According to FAO statistics, maize yields currently average $1.5 \mathrm{t} / \mathrm{ha}$ in Africa. Most of the crop is grown under dry land conditions by smallscale farmers, mainly for subsistence purposes and as part of a multi-enterprise agricultural system. This system often lacks inputs such as fertilizers, improved seed, irrigation and labor. In most developing countries there are very little purchased inputs for the cropping system and it mainly depends on the natural resource base Khan et al. [5] conducted an experiment on wheat variety Fakir-e-Sarhad, for four consecutive seasons (from 2000 to 2004) to study the effect of different organic materials alone and in combination with chemical fertilizers on the yield of wheat and physical properties of soil. In all the four seasons the maximum yield was given by the treatment i.e. (farm yard manure @ 10 ton ha ${ }^{-1}$ plus nitrogen, phosphorus and potassium at the rate of $120-90-60 \mathrm{~kg} \mathrm{ha}^{-1}$ ) while minimum grain yield was given by control.

\section{Moisture}

Leaf area is the measure of the photosynthetic system; it is the sum of all leaf lamina. All aspects of agricultural production are intimately associated with the growth of leaves because photosynthesisisusually proportional toleafarea. However, green leaf area does not always equate with actively photosynthesizing leaf area. Effects of drought may vary depending on the growth stage at which drought occurs and extreme water stress at different stages of crop development has been reported to reduce yield. Occurrence of drought stress at sowing reduces seedling germination and emergence. The reduction in growth during the vegetative stage is mainly due to the influence of drought on leaf expansion After emergence, plants respond to drought stress by reducing stomata conductance, thus reducing water loss. Reduced leaf turgid inhibits leaf expansion. This, in turn, leads to an increase in assimilate supply to the roots and increased root growth at the expense of above ground growth. found that maize stem height, leaf number and area as well as yield were reduced by water stress.

\section{Material and Methods}

\section{Experimental site}

An experiment was conducted at New Developmental Farm, The University of Agriculture Peshawar Pakistan. Peshawar is located about $1600 \mathrm{~km}$ north of Indian ocean and thus has a continental climate. The experimental site is located at $34 \mathrm{oN}$. $71.3 \mathrm{oE}$ and an altitude of 450 meter above sea level. The soil of experimental field was silty clay loam, low in nitrogen $(0.03-$ $0.04 \%)$, low in organic matter $(0.7-0.9 \%)$, and alkaline in reaction ( $\mathrm{pH} 8.0-8.2)$.

An experiment was to study the effect of seed priming, nitrogen and soil moisture regimes on yield and yield components of maize. The experiment was consisted of three factors i.e. moisture regimes (Low and High), seed priming (dry seed, water soaked, seed primed with $0.2 \%$ P solution) and nitrogen levels $\left(0,75,150 \mathrm{~kg} \mathrm{ha}^{-1}\right)$. Two separate experiments were conducted in RCBD, one under high moisture seedbed condition and other under low moisture seedbed condition. Treatment combination of seed priming and $\mathrm{N}$ levels were kept in both experiments with three replications. Low moisture plots were irrigated two weeks before sowing while high moisture plots were irrigated a week before sowing. Both low and high moisture plots were not irrigated till $40^{\text {th }}$ day after sowing. Soil moisture of both low and high moisture regimes were 23 and $30 \%$, respectively at the time of sowing of the crop. Maize variety Azam was sown at the rate of $120 \mathrm{~kg} \mathrm{ha}^{-1}$ in a subplot size of $5 \mathrm{~m}$ by $5 \mathrm{~m}$ having 6 rows meter long and $30 \mathrm{~cm}$ apart.

Nitrogen was applied in three split doses, one third each at sowing, tillering and boot stages. Seed priming was consisted of dry seed, water soaked seed and seed primed in $0.2 \% \mathrm{P}$ solution. $\mathrm{KH}_{2} \mathrm{PO}_{4}$ was used as source of P. For primed seeds, $180 \mathrm{~g}$ of seed per plot was sealed in perforated plastic bags and the bags were soaked for 12 hours in either distilled water or in a $0.2 \%$ aqueous solution of P. After soaking, bags were removed, drained and then surface dried in shade for around half an hour to facilitate clump-free sowing. Phosphorous at the rate of 90 $\mathrm{kg} \mathrm{ha}^{-1}$ was applied at sowing time. Sources of phosphorous and $\mathrm{N}$ were SSP and urea, respectively. All the standard agronomic practices were uniformly adopted for the experiment. 
Data were recorded on the following parameters:
A. Plant height
B. Leaf area
C. No of leaves per plot
D. Biological yield
E. Grain yield

\section{Plant height}

For recording data randomly selected 5 plants in each plot. Plant height was recorded at 14, 21, 28, 35 and 42 days after sowing were recorded.

\section{Leaf area}

Leaf area is recording by selecting 5 plants in each plot and find length and width of each leaf multiplying them. Leaf area was recording when emergence was completed.

\section{Number of leafs per plot}

Data of number of leafs are recoding after emergence by randomly selected 5 plants in each plot and number of leafs was recoding 14, 21, 28; 35.42 days after sowing were recorded.

\section{Biological yield}

Four central rows were harvested in each subplot and sun dried and bundles were weighed and its biological yield was converted into $\mathrm{kg} \mathrm{ha}^{-1}$ by the following formula:

Biological yield $\left(\mathrm{kg} \mathrm{ha}^{-1}\right)=$ Biological yield in three central rows $\mathrm{x} 10000$

\section{R-R $x$ No of rows $x$ row length}

\section{Grain yield}

Small wheat thresher was used for threshing the biological yield taken from four central rows in each sub plot. After threshing the grains were weighed by balance and were converted to $\mathrm{kg} \mathrm{ha}^{-1}$, using the formula: 10000

Grain yield $\left(\mathrm{kg} \mathrm{ha}^{-1}\right)=$ Grain yield in three central rows $\mathrm{x}$

$\mathrm{R}-\mathrm{R} \times \mathrm{No}$ of rows $\mathrm{x}$ row length

\section{Statistical Analysis}

The data were statistically analyzed using the procedure appropriate for RCB design with split plot arrangement upon obtaining significant F-values. The least significant difference (LSD) test was applied for the comparison of treatment means at $5 \%$ level of probability.

\section{Results}

\section{Plant height}

Data on plant height of maize are given in Table 1A \& $1 \mathrm{~B}$. Analysis of data showed that the effects of moisture, $\mathrm{N}$ levels and seed priming were not significant while plant height significantly varied during different weeks. Similarly, all interaction were remained non-significant. Plant height significantly enhanced from week first to fifth week. It increased from $4.20 \mathrm{~cm}$ to 7.10 $\mathrm{cm}(46 \%)$ during first week. During second week, it increased from $7.10 \mathrm{~cm}$ to $7.40 \mathrm{~cm} \mathrm{(3 \% ).} \mathrm{In} \mathrm{week} \mathrm{third,} \mathrm{it} \mathrm{increased} \mathrm{from}$ $7.40 \mathrm{~cm}$ to $10.30 \mathrm{~cm} \mathrm{(30 \% ).} \mathrm{It} \mathrm{increased} \mathrm{from} 10.30 \mathrm{~cm}$ to $11.60 \mathrm{~cm}$ (2.5\%) during week four. Similarly, in week five, it increased from $11.60 \mathrm{~cm}$ to $14.50 \mathrm{~cm}$ (23\%). Plant height was significantly affected by moisture, $\mathrm{N}$ levels and seed priming while the effect of different weeks was significant. The results are similar with who found that irrigation increased the heading and stem elongation. Arif et al. 2006 reported significant increase in plant height of maize with application of nitrogen. Similarly, Khan and Khalil [5] found taller plants in plots having seeds treated with phosphorus solution.

Table 1A: Physico-chemical properties of test soil.

\begin{tabular}{|c|c|}
\hline Properties & Values \\
\hline clay\% & 4.46 \\
\hline silt $\%$ & 46 \\
\hline sand\% & 49 \\
\hline textural class & sandy loam \\
\hline pH(1:5) & 8 \\
\hline Available phosphorus $(\mathrm{mg} / \mathrm{kg})$ & 11 \\
\hline
\end{tabular}

Table 1B: Plant height as affected byPrimed (water or $0.2 \% \mathrm{P}$ ) and un-primed with different nitrogen levels.

\begin{tabular}{|c|c|c|c|c|}
\hline \multicolumn{5}{|c|}{ Mean table } \\
\hline $\begin{array}{c}\text { Seed } \\
\text { priming }\end{array}$ & $\mathrm{N}_{1} 0$ & $\mathrm{~N}_{2} 75$ & $\mathrm{~N}_{3} 150$ & Mean \\
\hline No priming & 78 & 97 & 88 & 88 \\
\hline W. priming & 93 & 96 & 98 & 96 \\
\hline P. priming & 88 & 95 & 84 & 89 \\
\hline Mean & 86 & 96 & 90 & \\
\hline
\end{tabular}

\section{Leaf area}

Table 2: Leaf area as affected by Primed (water or $0.2 \% \mathrm{P}$ ) and unprimed with different nitrogen levels.

\begin{tabular}{|c|c|c|c|}
\hline & T inverse & SE & LSD \\
\hline N & 2.119905 & 0.82 & 1.75 \\
\hline SP & 2.119905 & 0.82 & 1.75 \\
\hline N X P & 2.119905 & 2.47 & 5.25 \\
\hline
\end{tabular}

\begin{tabular}{|c|c|c|c|c|}
\hline \multicolumn{5}{|c|}{ Mean table } \\
\hline $\begin{array}{c}\text { Seed } \\
\text { priming }\end{array}$ & N10 & N2 75 & N3 150 & Mean \\
\hline No priming & 218 & 206 & 212 & 212 \\
\hline W. priming & 238 & 208 & 228 & 225 \\
\hline P. priming & 260 & 264 & 249 & 258 \\
\hline Mean & 239 & 226 & 230 & \\
\hline
\end{tabular}




\begin{tabular}{|c|c|}
\hline Weeks & Plant height \\
\hline & In $(\mathbf{c m})$ \\
\hline 1 & $4.20 \mathrm{~d}$ \\
\hline 2 & $7.10 \mathrm{c}$ \\
\hline 3 & $7.40 \mathrm{c}$ \\
\hline 4 & $10.30 \mathrm{~b}$ \\
\hline 5 & $11.60 \mathrm{~b}$ \\
\hline 6 & $14.50 \mathrm{a}$ \\
\hline LSD & $\mathbf{2 . 8 8}$ \\
\hline
\end{tabular}

Data regarding leaf area of maize are given in Table 2A\&2B. Results shows that the leaf area were affected due to low irrigation level and priming. Analysis of data showed that the effects of moisture, $\mathrm{N}$ levels and seed priming significantly affected leaf area and also varied during different weeks. The mean average shows that those unprimed seed will have less leaf area then primed seed but the phosphorus primed seed will have more leaf area than water primed.

\section{Number of leaves}

Data regarding number of leaves of maize are given in Table 2. Analysis of data showed that the effects of moisture, $\mathrm{N}$ levels and seed priming were not significant while number of leaves significantly varied during weeks. All interactions were not significant. Number of leaves significantly increased with the passage of time. It increased from 2.0 to 5.44 (68.8\%) during first week. During second week, it increased from 5.44 to 7.0 (18.4\%). In week third, it increased from 7.0 to 11.13 (41\%). It increased from 11.13 to 12.70 (11\%) during week four. Similarly, in week five, it increased from 12.70 to 15.03 (2\%)(Table 3).

Table 3: Number of leaves as affected by Primed (water or $0.2 \% \mathrm{P}$ ) and un-primed with different nitrogen levels.

\begin{tabular}{|c|c|c|c|}
\hline & T inverse & SE & LSD \\
\hline N & 2.119905 & 0.07 & 0.14 \\
\hline SP & 2.119905 & 0.07 & 0.14 \\
\hline N X P & 2.119905 & 0.2 & 0.42 \\
\hline
\end{tabular}

\begin{tabular}{|c|c|c|c|c|}
\hline \multicolumn{5}{|c|}{ Mean table } \\
\hline $\begin{array}{c}\text { Seed } \\
\text { priming }\end{array}$ & $\mathrm{N}_{1} 0$ & $\mathrm{~N}_{2} 75$ & $\mathrm{~N}_{3} 150$ & Mean \\
\hline No priming & 12 & 11 & 12 & 12 \\
\hline W. priming & 12 & 11 & 11 & 11 \\
\hline P. priming & 13 & 12 & 11 & 12 \\
\hline Mean & 12 & 12 & 12 & \\
\hline
\end{tabular}

\section{Biological yield}

Table 4: Biological yield as affected by Primed (water or $0.2 \% \mathrm{P}$ ) and un-primed with different nitrogen levels.

\begin{tabular}{|c|c|c|c|}
\hline & T inverse & SE & LSD \\
\hline N & 2.119905 & 105.27188 & 223.1664 \\
\hline SP & 2.119905 & 105.27188 & 223.1664 \\
\hline N X P & 2.119905 & 315.81564 & 669.4992 \\
\hline
\end{tabular}

\begin{tabular}{|c|c|c|c|c|}
\hline \multicolumn{5}{|c|}{ Mean table } \\
\hline $\begin{array}{c}\text { Seed } \\
\text { priming }\end{array}$ & $\mathrm{N}_{1} 0$ & $\mathrm{~N}_{2} 75$ & $\mathrm{~N}_{3} 150$ & Mean \\
\hline No priming & 1950 & 4599 & 6147 & 4232 \\
\hline W. priming & 2645 & 5074 & 8555 & 5424 \\
\hline P. priming & 3440 & 5259 & 9674 & 6124 \\
\hline Mean & 2678 & 4977 & 8125 & \\
\hline
\end{tabular}

Data regarding biological yield of maize are given in Table 4. Analysis of the data revealed that nitrogen levels and seed priming significantly affected biological yield of maize. The effect of moisture was not significant. Similarly, all the interactions were not significant. Biological yield increased with increasing level of $\mathrm{N}$ and priming. Higher biological yield was obtained at $150 \mathrm{~kg} \mathrm{~N} \mathrm{ha}^{-1}$ (9674 $\mathrm{kg} \mathrm{ha}^{-1}$ ) followed by $\mathrm{N}$ level of $75 \mathrm{~kg} \mathrm{~N} \mathrm{ha}^{-1}$ (5259kg ha-1). Minimum biological yield (3440 $\mathrm{kg} \mathrm{ha}^{-1}$ ) was obtained at $0 \mathrm{~kg} \mathrm{~N} \mathrm{ha}^{-1}$. Seed priming improved biological yield.

\section{Grain yield}

Table 5: Grain yield as affected by Primed (water or $0.2 \% \mathrm{P}$ ) and unprimed with different nitrogen levels.

\begin{tabular}{|c|c|c|c|}
\hline & T inverse & SE & LSD \\
\hline N & 2.119905 & 1.11 & 2.36 \\
\hline SP & 2.119905 & 1.11 & 2.36 \\
\hline N X P & 2.119905 & 3.34 & 7.07 \\
\hline
\end{tabular}

\begin{tabular}{|c|c|c|c|c|}
\hline \multicolumn{5}{|c|}{ Mean table } \\
\hline $\begin{array}{c}\text { Seed } \\
\text { priming }\end{array}$ & $\mathrm{N}_{1} 0$ & $\mathrm{~N}_{2} 75$ & $\mathrm{~N}_{3} 150$ & Mean \\
\hline No priming & 139 & 140 & 143 & 140 \\
\hline W. priming & 145 & 137 & 154 & 145 \\
\hline P. priming & 140 & 141 & 162 & 148 \\
\hline Mean & 141 & 139 & 153 & \\
\hline
\end{tabular}

Data regarding grain yield of maize are given in Table 5. Analysis of the data revealed that nitrogen levels and seed priming significantly affected grain yield of maize. The effect of moisture was not significant. Similarly, all the interactions were not significant. Grain yield increased with increasing level of $\mathrm{N}$. Higher grain yield was obtained at $150 \mathrm{~kg} \mathrm{~N} \mathrm{ha}^{-1}\left(3433 \mathrm{~kg} \mathrm{ha}^{-1}\right)$ followed by $\mathrm{N}$ level of $75 \mathrm{~kg} \mathrm{~N} \mathrm{ha}^{-1}$ (3011 $\mathrm{kg} \mathrm{ha}^{-1}$ ). Minimum grain yield (2160 $\left.\mathrm{kg} \mathrm{ha}^{-1}\right)$ was obtained at $0 \mathrm{~kg} \mathrm{ha}^{-1}$.

\section{Discussion}

Plant height was significantly affected by moisture, $\mathrm{N}$ levels and seed priming while the effect of different weeks was significant. Plant height increased 46, 3, 30, 2.5 and 23\% during first, second, third, fourth and fifth week, respectively. The 
results are similar with who found that irrigation increased the heading and stem elongation. Arif et al. 2006 reported significant increase in plant height of maize with application of nitrogen. Similarly, Khan and Khalil [4] found taller plants in plots having seeds treated with phosphorus solution.

Number of leaves was not significantly affected by moisture, $\mathrm{N}$ levels and seed priming while the effect of different weeks was significant. Number of leaves increased 68, 18.4, 41, 11 and 2\% during first, second, third, fourth and fifth week, respectively. Dissimilar results have reported by Sharp and Davies, (1989). They found that shoot is critical than root of a plant and among the shoot leaf is the sensitive part which affected adversely when soil moisture content decreased. Results are not in line with Kasem and Mesilhy (1992) who found that nitrogen increased number of leaves per plant.

Biological yield was significantly affected by nitrogen levels and seed priming while moisture effect was not significant. Biological yield increased with increasing level of N. Higher biological yield was obtained at $150 \mathrm{~kg} \mathrm{~N} \mathrm{ha}^{-1}$ followed by $\mathrm{N}$ level of $75 \mathrm{~kg} \mathrm{~N} \mathrm{ha}^{-1}$. Minimum biological yield was obtained at $0 \mathrm{~kg} \mathrm{~N}$ ha $^{-1}$. Seed priming improved biological yield. Higher biological yield was recorded for P primed seed and water soaked while dry seed resulted in lower biological yield. These results are dissimilar with Tahmasabi et al. (2000) who reported that biological yield increased as number of irrigations increased. The results are in agreement with Zubair et al. (2009) who stated that higher $\mathrm{N}$ levels increased vegetative growth which enhanced biological yield. These results endorse the findings of Basra et al. (2003) and Rashid et al. (2002) who reported that primed seed significantly increased total biomass and dry weight as compared to control.

Grain yield of maize was significantly affected by nitrogen levels and seed priming while moisture effect was not significant. Grain yield increased with increasing level of N. Higher grain yield was obtained at $150 \mathrm{~kg} \mathrm{~N}^{-1}$ followed by $\mathrm{N}$ level of $75 \mathrm{~kg} \mathrm{~N}$ $\mathrm{ha}^{-1}$. Minimum grain yield was obtained at $0 \mathrm{~kg} \mathrm{ha}^{-1}$. Seed priming improved grain yield. Higher grain yield was recorded for $\mathrm{P}$ primed and water soaked seed. Lower grain yield was recorded for dry seed. These results are in disagreement with Pandey et al. (2001) who found linear response between number of irrigations and grain yield. These results are in agreement with Ortiz Monasterio et al. (1997) who reported that N application increased biomass and grain yield of the crop. Goshet al.(1997) reported higher grain yield for priming as compared to control. Seed priming with water alone is also effective insubstantially increasing yields of maize Harris et al. [6] and Rashid et al. [2].

\section{Summary}

The experiment was conducted at New Developmental Farm, The University of Agriculture Peshawar during summer 2013 to study the effect of seed priming, nitrogen and soil moisture regimes on yield and yield components of maize. Two separate experiments were conducted in RCB design, one under high moisture condition other under low moisture condition. Treatment combination of seed priming and $\mathrm{N}$ levels were kept in. sub plots while moisture in main plots. Nitrogen was applied in three split doses $\left(0,75,150 \mathrm{~kg} \mathrm{~N}^{-1}\right)$ one third each at sowing, tillering and boot stages. Seed priming was consisted of dry seed, water soaked and seed primed in $0.2 \%$ P solution.

Days to emergence of maize were significantly affected by moisture and seed priming while nitrogen effect was not significant. Low moisture plots resulted in higher days to emergence as compared to high moisture plots. Higher days to emergence were recorded for dry seed as compared to $\mathrm{P}$ primed seed and water soaked seed which took lower days to emergence. Emergence $\mathrm{m}^{-2}$ was significantly affected by moisture and seed priming while the effect of nitrogen levels was not significant High moisture plots resulted in higher emergence $\mathrm{m}^{-2}$ as compared to low moisture plots. P primed seed and water soaked seed resulted in higher emergence $\mathrm{m}^{-2}$ as compared to dry seed. Plant height was not significantly affected by moisture, $\mathrm{N}$ levels and seed priming while the effect of different weeks was significant. Plant height increased 46, 3, 30, 2.5 and 23\% during first, second, third, fourth and fifth week, respectively Number of leaves was not significantly affected by moisture, $\mathrm{N}$ levels and seed priming while the effect of different weeks was significant.

Number of leaves increased 68, 18.4, 41, 11 and 2\% during first, second, third, fourth and fifth week, respectively. Biological yield was significantly affected by nitrogen levels and seed priming while moisture effect was not significant. Higher biological yield was obtained at $150 \mathrm{~kg} \mathrm{~N}^{-1}$ hollowed by $\mathrm{N}$ level of $75 \mathrm{~kg} \mathrm{~N}^{-1}$. Minimum biological yield was obtained at $0 \mathrm{~kg} \mathrm{~N}$ ha $^{-1}$. Higher biological yield was recorded for P primed seed and water soaked seed while dry seed resulted in lower biological yield. Grain yield of maize was significantly affected by nitrogen levels and seed priming while moisture effect was not significant. Higher grain yield was obtained at $150 \mathrm{~kg} \mathrm{~N}^{-1}$ followed by $\mathrm{N}$ level of $75 \mathrm{~kg} \mathrm{~N}^{-1}$. Minimum grain yield was obtained at $0 \mathrm{~kg}$ $\mathrm{N} \mathrm{ha}^{-1}$. Higher grain yield was recorded for $\mathrm{P}$ primed and water soaked seed. Lower grain yield was recorded for dry seed [7-12].

\section{Conclusion and Recommendations}

\section{From the above results it is concluded that}

High moisture (seedbed) resulted in higher yield and yield components as compared to low moisture seedbed. Nitrogen application at the rate of $150 \mathrm{~kg} \mathrm{~N} \mathrm{ha}^{-1}$ produced higher grain yield and yield components as compared to other levels. $\mathrm{P}$ primed seed resulted in higher grain yield and yield components as compared to water soaked and dry seed.

\section{Recommendations}

High moisture seedbeds are recommended to the farmers for higher yield and yield components of maize.

Fertilizer $\mathrm{N}$ application at the rate of $150 \mathrm{~kg} \mathrm{ha}^{-1}$ in split dose is recommended to the farmers on the basis of yield performance. 
P priming is recommended to the farmers on the basis of good crop stand and yield performance.

\section{References}

1. Arif M, Ali S, Shah A, Javed N, Rashid A (2005) Seed priming maize for improving emergence in seedling growth. Sarhad J Agric 21(4): 539543

2. Rashid A, Hollington PA, Harris D, Khan P (2005) On-farm seed priming for barley on normal, saline and saline-sodic soil $s$ in North West Frontier Province, Pakistan. Europe J Agron 24(6): 276-281.

3. Arif M, Chohan MA, Ali S, Gull R, Khan S (2006) Response of wheat to foliar application of nutrients. American Journal of Agricultural and Biological Science 1(4): 30-34.

4. Khan S, Khalil SK (2007) Effect of seed priming with phosphorus concentration and application rates on wheat. NWFP Agricultural University Peshawar, Pakistan.

5. Khan A, Khalil SK, Khan S, Afzal A (2006) Priming effects crop stand of mugbean. Sarhad J Agric 21(4): 535-538.

6. Harris D, Rashid A, Ali S, Hollington PA (2004) On-farm seed priming with maize in Pakistan. In: Srinivasan and Zaidi PH, et al. (Eds) proceeding of the $8^{\text {th }}$ Asian Regional Maize Works hoop: New
Technologies for the New Millennium held Bangkok, Thailand CIMMYT, Mexico, pp. 316-324.

7. Afzal A, Khalil SK, Abdullah, Khan A (2005) Effect of polyethylene Glycol concentrations and duration on mug been. Sarhad J Agric 21: 171-175.

8. Brahma R, Jana wade AD, Palled YB (2006) Effect of irrigation schedules on Growth, Yield and Economics of wheat (cv. DWD-106). Karnataka J Agric Sci 20(1): 6-9.

9. MINFAL (2009) Agricultural statistics of Pakistan. Govt. of Pakistan. Ministry of food - Agri. Livestock, Food Agriculture and livestock, Division (Economic wing) Islamabad, Pakistan.

10. Muringu FS, Chiduza C, Nyamugafata P, Clark LJ, Whaley WR, et al (2004) Effect of on-farm seed priming on consecutive daily sowing occasions on the emergence and growth of maize in semi-arid Zimbabwe. Field Crops Research 89(1): 49-57.

11. Shatab, Khan S (2007) The effect of priming and P levels on wheat crop. MSc (Hons) thesis, Department of Agronomy, Agri Uni, Peshawar, USA, pp. 53-54.

12. Subedi KD, Ma LB (2005) Seed Priming does not improve corn yield in a humid temperature environment. American Soci of Agron J 97: 211218. 